\title{
Expression of foreign genes and selection of promoter sequences in Acholeplasma laidlawii
}

\author{
Tanja K. Jarhede, † Michel Le Hénaff $\ddagger$ and Åke Wieslander \\ Author for correspondence: Tanja K. Jarhede. Tel: +469016 64 99. Fax: +4690167661.
}

Department of

Biochemistry, Umeå

University, S-901 87 Umeå,

Sweden

\begin{abstract}
The stable maintenance and expression of foreign genes in mollicutes (mycoplasmas) have been difficult to achieve due to the lack of suitable vectors. In this paper we show for the first time that a replicating vector can been used to express foreign genes other than antibiotic resistance genes in Acholeplasma laidlawii. Plasmids derived from the lactococcal vector pNZ18 could introduce and maintain four different genes for many generations in A. laidlawii. One of these, encoding the dominant membrane lipoprotein spiralin from the mollicute Spiroplasma citri, was expressed; however, expression was weak, the signal peptide of spiralin was not cleaved and the protein was not covalently modified by fatty acids. This resulted in a hydrophilic character of spiralin and its cytoplasmic localization in A. laidlawii. To increase the expression of foreign genes, random A. laidlawii DNA fragments were cloned into a pNZ18-related plasmid and expression signals were selected using the Bacillus licheniformis $\alpha$-amylase gene as a probe. Selection was done in Escherichia coli as well as directly in A. laidlawii. Active recombinants from $E$. coli were also able to express $\alpha$-amylase activities and an enzyme of native size in A. laidlawii. The highest activity was obtained from a recombinant selected directly in A. laidlawii. This is the first example of a promoter sequence selected in a mollicute. Analysis of the putative promoters in seven clones revealed similar -10 and -35 regions, and similar spacer distances in $A$. laidlawii, Acholeplasma oculi, Lactococcus and E. coli. Vectors related to pNZ18 should be useful for the genetic analysis of specific A. laidlawii proteins and functions.
\end{abstract}

Keywords: mollicutes, Acholeplasma laidlawii, plasmid transformation, expression, promoters

\section{INTRODUCTION}

Mollicutes (mycoplasmas) are small cell wall-less bacteria of Gram-positive origin, usually found as cell-surface parasites in humans, animals, plants and insects (Maniloff et al., 1992). A marked decrease in genome size, during the evolution, has been accompanied by a change of the normal stop codon UGA to a Trp codon in several genera. The species Acholeplasma laidlawii, having a normal Trp codon (Tanaka et al., 1989), has contributed important knowledge about basic physical properties of lipid bilayers in biological membranes (Singer \&

†Previously Sundstrom.

$\ddagger$ Present address: Université de Rennes I, L.I.M.B.-CNRS URA 256, Campus de Beaulieu, F-35042 Rennes Cédex, France.
Nicolson, 1972). We have shown that certain packing properties are metabolically maintained constant among the membrane lipids (reviewed in Rilfors et al., 1993). Similar principles seem to operate in several other bacteria and organelles (Rietveld et al., 1993; Wieslander et al., 1994). Other special features of $A$. laidlawii, and also many other mollicutes, include modification of many membrane proteins with specific fatty acid chains (Wieslander et al., 1992).

A genetic analysis of these, and other mechanisms in $A$. laidlawii, demands efficient vectors and a good expression of introduced genes other than the genes involved in vector functions. Neither have been obtained (Dybvig, 1992). Hence, development of plasmid and other vectors adapted to $A$. laidlawii are needed. A lactococcal plasmid (pNZ18), able to replicate in several Gram-positive bacteria and in Escherichia coli, yielded acceptable trans- 
formation frequencies and was stably maintained in $A$. laidlawii (Sundström \& Wieslander, 1990). This report deals with the cloning of foreign genes from which fullsize proteins were expressed in $A$. laidlawii, as well as the selection of suitable promoter sequences, using plasmids related to pNZ18. The following genes coding for different types of proteins were tested for expression in $A$. laidlawii: the spiralin gene encoding the major membrane lipoprotein in Spiroplasma citri (Wróblewski et al., 1977; Mouchès et al., 1985; Bové et al., 1993); an A. laidlawii gene coding for E2p, a subunit of the pyruvate dehydrogenase enzyme complex (Wallbrandt et al., 1992); a $\beta$-lactamase gene from $E$. coli; and an $\alpha$-amylase gene from Bacillus licheniformis. The two latter genes are efficient and much used probes for membrane protein topology (Broome-Smith et al., 1990) and secretion studies (Simonen \& Palva, 1993), respectively. A. laidlawii promoter sequences were selected in both $A$. laidlawii and $E$. coli with the help of a promoter-less $\alpha$-amylase gene. These selected sequences will be useful in increasing the expression of heterologous genes in $A$. laidlawii.

\section{METHODS}

Bacterial strains and culture conditions. A. laidlawii strain 8195 (Sladek et al., 1986), clone 2501, which can be transformed to a relatively high frequency (Sundström \& Wieslander, 1990), was used. The cells were grown without shaking at $37^{\circ} \mathrm{C}$ for $24-48 \mathrm{~h}(2-10 \%, \mathrm{v} / \mathrm{v}$, inoculation), in a BSA-tryptose medium (Wallbrandt et al., 1992) supplemented with $75 \mu \mathrm{M}$ palmitic acid and $75 \mu \mathrm{M}$ oleic acid. Solid medium was made by addition of $1 \cdot 2 \%(w / v)$ agar. E. coli MC1061 (Casadaban \& Cohen, 1980) was grown with shaking at $37^{\circ} \mathrm{C}$ overnight in Luria-Bertani medium. S. citri Maroc R8A2 ${ }^{\mathrm{T}}$ (ATCC $27556^{\mathrm{T}}$; Saglio et al., 1973) was grown without shaking at $32^{\circ} \mathrm{C}$ for $48 \mathrm{~h}(10 \%$ inoculation) in BSR medium (Whitcomb, 1983).

Labelling with radioactive fatty acids. $A$. laidlawii medium was supplemented with $30 \mathrm{mCi}^{-1}\left(1 \cdot 11 \mathrm{GBq} \mathrm{l}^{-1}\right)(1 \cdot 36 \mu \mathrm{M})^{3} \mathrm{H}$ labelled or $2 \mathrm{mCi}^{-1}\left(74 \mathrm{MBq}^{-1}\right)(37 \cdot 0 \mu \mathrm{M}){ }^{14} \mathrm{C}$-labelled palmitic acid (New England Nuclear). PMSF was added to $1 \mathrm{mM}$ in all solutions in the harvesting procedure (below). Membrane lipids were extracted with 20 volumes ice-cold ethanol overnight at $-20^{\circ} \mathrm{C}$. The proteins were sedimented by centrifugation. The extraction was continued with cold ethanol followed by ethanol/diethyl ether $(1: 1, \mathrm{v} / \mathrm{v})$ and diethyl ether. Proteins in pellets were analysed by SDS-PAGE (see below) and immunoblotting. Gels and immunoblot membranes were processed for fluorography or autoradiography by standard procedures.

Preparation of $\boldsymbol{A}$. laidlawii membrane and cytoplasmic fractions. $A$. laidlawii cells were harvested by centrifugation, washed with $\beta$-buffer $(0.15 \mathrm{M} \mathrm{NaCl}, 0.05 \mathrm{M}$ Tris/HCl, $\mathrm{pH} 7 \cdot 4)$, frozen in water overnight, and lysed by stirring for $2 \mathrm{~h}$ at $37^{\circ} \mathrm{C}$ as in Nyström et al. (1986). Membranes were collected by centrifugation at $48000 g_{\max }$ for $1.5 \mathrm{~h}$ at $5{ }^{\circ} \mathrm{C}$ and washed once in diluted $\beta$-buffer $(1: 20, \mathrm{v} / \mathrm{v})$. The supernatant (cytoplasm) was lyophilized. For some studies of spiralin, the cytoplasmic fraction was separated from small amounts of contaminating membrane proteins by ultracentrifugation twice at $265000 g_{\max }$ for $30 \min$ at $4{ }^{\circ} \mathrm{C}$. For $\alpha$-amylase analysis, cells were grown for $24 \mathrm{~h}$, washed and suspended in $\beta$-buffer, lysed by sonication $\left(2 \times 1 \mathrm{~min}\right.$ at $70 \mathrm{~W}$ and $\left.0^{\circ} \mathrm{C}\right)$, and centrifuged $\left(12000 \mathrm{~g}_{\max }\right.$ for $30 \mathrm{~min}$ at $4{ }^{\circ} \mathrm{C}$ ) to separate fractions enriched in membrane and cytoplasm.
Plasmids. The plasmids pNZ18 and pNZ19 (Table 1 and Fig. 1a) are modified Lactococcus lactis plasmids with a broad hostrange (de Vos, 1987; Sundström \& Wieslander, 1990). Both plasmids are derived from pNZ12. The plasmid pNZ18H was constructed by inserting a HindIII linker with the sequence $5^{\prime}$ CAAGCTTG-3' in the PvuII site in PNZ18.

Plasmid pGIP312 (Table 1 and Fig. 1b) (Hols et al., 1992) contains a truncated $\alpha$-amylase gene (amyL) from $B$. licheniformis (Piggot et al., 1984). The $\alpha$-amylase gene lacks a promoter, RBS and the $5^{\prime}$-fragment encoding the signal peptide. The replicon and two of the resistance genes are from pNZ12. A terminator from the phage T4 gene 32 is inserted in front of the $\alpha$-amylase gene (Prentki \& Krisch, 1984).

Cloning of genes. A DNA fragment (968 bp) containing the spiralin gene and its proposed promoter, RBS and transcription terminator was amplified from plasmid pES1 (Mouchès et al., 1985; Chevalier et al., 1990a) by PCR. The primer for the $3^{\prime}$ end was modified with a HindIII site and the other primer with a PstI site. Plasmid pNZ18H and the PCR products were cut with HindIII and Pst I and ligated together, yielding plasmid pNZ18HS. A larger SacI/BstEII fragment was cut out of pNZ18HS, and ligated into pNZ19 (Fig. 1a).

Random fragments of $A$. laidlawii genomic DNA partially digested with Sau3A, $A$ luI or RsaI, have been inserted in front of a truncated $\beta$-lactamase gene (T.K. Jarhede et al., unpublished results) in the signal sequence selection vector pGPB14 (Smith et al., 1987). From one of the selected clones (pALE102), the $A$. laidlawii insert (1.3 kbp) and the in-frame $\beta$ lactamase gene $(1.3 \mathrm{kbp})$ was excised and ligated into $\mathrm{pNZ} 18 \mathrm{H}$.

A $3^{\prime}$-truncated dihydrolipoamide acetyltransferase (E2p) gene from $A$. laidlawii (Wallbrandt $e t$ al., 1992) was excised from the plasmid pB15 (Tegman et al., 1987) and ligated into pNZ18H. The 3'-truncated form of the gene was used to separate the cloned E2p from the naturally occurring E2p. It encodes a peptide of $43 \mathrm{kDa}$ instead of $75 \mathrm{kDa}$ for the native one (as judged from SDS-PAGE).

To construct a library of expression signals from $A$. laidlawii, genomic DNA was partially digested with Sau3A. The fragments obtained were ligated into a unique $\mathrm{Bam} \mathrm{HI}$ site in front of the truncated $\alpha$-amylase gene of pGIP312 (Fig. 1b). Expression of the amyL gene was first assayed in E. coli by iodine plate tests (see below). The plasmids with random inserts initially selected in $E$. coli were also used to transform $A$. laidlawii cells. The transformants were analysed for the production of $\alpha$-amylase in starch-agar plates (see below). In another experiment, $A$. laidlawii cells were directly transformed by plasmids with inserted $S a$ u 3 A fragments. Plasmids from the positive clones found here were also used to transform E. coli.

Plasmid preparations and transformation of cells. Plasmids were isolated according to the alkaline lysis method (Sambrook et al., 1989). Transformation of competent E. coli (Hanahan, 1985) was performed as described by Sambrook et al. (1989). Transformants were selected on agat plates containing $10 \mu \mathrm{g}$ chloramphenicol $\mathrm{ml}^{-1}$ or $10 \mu \mathrm{g}$ chloramphenicol ml $\mathrm{ml}^{-1}$ plus $12.5 \mu \mathrm{g}$ streptomycin $\mathrm{ml}^{-1}$. PEG-dependent transformation of A. laidlawii was done as described by Sladek \& Maniloff (1983) with modifications as in Sundström \& Wieslander (1990). Neomycin $\left(40 \mu \mathrm{g} \mathrm{ml}^{-1}\right)$ was used in the agar plates. The transformation frequency was $4 \times 10^{-4}$ c.f.u. $^{-1}$, which corresponded to $4 \times 10^{3}$ transformants per $\mu \mathrm{g}$ DNA; non-transformed cells could not grow on plates with neomycin. 
Table 1. Plasmids used in this study

\begin{tabular}{|c|c|c|c|}
\hline Plasmids & $\begin{array}{l}\text { Size } \\
(\mathrm{kbp})\end{array}$ & Genes and relevant features & Reference \\
\hline $\mathrm{pNZ12}$ & $4 \cdot 3$ & Promiscuous L. lactis plasmid & de Vos (1987) \\
\hline pNZ18 & $5 \cdot 7$ & $\begin{array}{l}\text { Derivate of pNZ12 with cloning } \\
\text { cassette from } \mathrm{pJRD} 158\end{array}$ & $\begin{array}{l}\text { de Vos (1987); de Vos, } \\
\text { personal communication }\end{array}$ \\
\hline pNZ18H & $5 \cdot 7$ & $\begin{array}{l}\text { pNZ18 with HindIII site instead of } \\
\text { PvuII }\end{array}$ & This paper \\
\hline pNZ19 & $5 \cdot 7$ & $\begin{array}{l}\text { As pNZ18 but orientation of } \\
\text { Xhol } / \text { Sall fragment of } \mathrm{pJRD} 158 \text { is } \\
\text { reversed }\end{array}$ & $\begin{array}{l}\text { de Vos, } \\
\text { personal communication }\end{array}$ \\
\hline pES1 & $11 \cdot 4$ & $\begin{array}{l}\text { pBR328 vector with spiralin gene, } \\
r p s B, t s f, p f k \text { and } p y k \text { from } S . \text { citri }\end{array}$ & $\begin{array}{l}\text { Chevalier et al. (1990a); } \\
\text { Mouchès et al. (1985) }\end{array}$ \\
\hline pGIP312 & $8 \cdot 3$ & $\begin{array}{l}\text { Expression/secretion signal vector } \\
\text { carrying the truncated amyL gene } \\
\text { and the same replicon as pNZ18 }\end{array}$ & Hols et al. (1992) \\
\hline pGPB14 & $5 \cdot 7$ & $\begin{array}{l}\text { Expression/secretion signal vector } \\
\text { with truncated } \beta \text {-lactamase gene }\end{array}$ & Smith et al. (1987) \\
\hline $\mathrm{pB} 15$ & $7 \cdot 9$ & $\begin{array}{l}\text { Vector pAT153 (pBR322 } \\
\text { derivative) with pyruvate } \\
\text { dehydrogenase operon }\end{array}$ & $\begin{array}{l}\text { Tegman et al. (1987); } \\
\text { Wallbrandt et al. (1992) }\end{array}$ \\
\hline pNZ18HS & $6 \cdot 2$ & $\begin{array}{l}\text { pNZ18H with spiralin gene from } \\
\text { pES1 }\end{array}$ & This paper \\
\hline pNZ19HS & $6 \cdot 2$ & $\begin{array}{l}\text { pNZ19 with spiralin gene from } \\
\text { pNZ18HS }\end{array}$ & This paper \\
\hline pNZ18H.102 & $8 \cdot 3$ & $\begin{array}{l}\text { pNZ18H with } \beta \text {-lactamase gene } \\
\text { from pGBP14 and an } A \text {. laidlawii } \\
\text { DNA fragment }\end{array}$ & This paper \\
\hline pNZ18H.E2p & $8 \cdot 2$ & $\begin{array}{l}\mathrm{pNZ18H} \text { with a truncated E2p } \\
\text { from } \mathrm{pB} 15\end{array}$ & This paper \\
\hline pALP30 & $8 \cdot 3$ & $\begin{array}{l}\text { pGIP312 with inserted small } A \text {. } \\
\text { laidlawii DNA fragment. Selected } \\
\text { in } A \text {. laidlawii } \\
\text { pALP21 }\end{array}$ & This paper \\
\hline $\left.\begin{array}{l}\text { pALP35 } \\
\text { pALP52 } \\
\text { pALPA } \\
\text { pALB } \\
\text { pALPI } \\
\text { pALPJ }\end{array}\right\}$ & $8 \cdot 3$ & $\begin{array}{l}\text { pGIP312 with inserted small } A \text {. } \\
\text { laidlawii DNA fragments. Selected in } \\
E . \text { coli }\end{array}$ & This paper \\
\hline
\end{tabular}

SDSPAGE and immunoblotting. Samples with spiralin were separated in SDS-polyacrylamide gels in a modified Neville system (Nyström et al., 1986). Expression of $\alpha$-amylase was analysed in $10 \%(\mathrm{w} / \mathrm{v})$ polyacrylamide gels (Laemmli, 1970). Gels were stained with Coomassie Brilliant Blue, assayed for $\alpha$ amylase activity or semi-dry electroblotted onto Immobilon-P transfer membranes (Millipore) (Wallbrandt et al., 1992). Primary antibodies (polyclonal and monoclonal, kindly provided by $\mathrm{H}$. Wróblewski, Rennes, France) directed against $S$. citri spiralin, and alkaline phosphatase- or peroxidaseconjugated secondary antibodies were used.

Electroelution and $\mathbf{N}$-terminal amino acid sequencing. Preparative gels (thickness $1.5 \mathrm{~mm}$ ) were aged $24 \mathrm{~h}$ before electrophoresis. A gel slice corresponding to the spiralin band was excised from stained gels and stored frozen before electroelution (BioRad electro-eluter model 422 ) in $50 \mathrm{mM}$ $\mathrm{NH}_{4} \mathrm{HCO}_{3}$ and $0.1 \%$ SDS. The samples were then electrodialysed in the same equipment in $50 \mathrm{mM} \mathrm{NH} \mathrm{NHCO}_{3}$ and $0.01 \%$ SDS to reduce the amount of SDS. Samples from 10 gels were pooled, lyophilized and separated by another SDS-PAGE (as above). Processing of proteins for amino acid sequencing was performed essentially as described by Matsudaira (1987) and by Nyström et al. (1992). Proteins were semi-dry blotted onto Trans-Blot transfer membranes (BioRad) and processed as described by the manufacturer. A strip of the membrane, corresponding to the visualized spiralin band was cut out and subjected to sequencing.

Determination of the $\mathrm{N}$-terminal amino acid sequence of spiralin was performed with a gas-phase sequencer (Applied Biosystem $477 \mathrm{~A}$ ) equipped with an on-line phenylthiohydantoin amino 
(a)

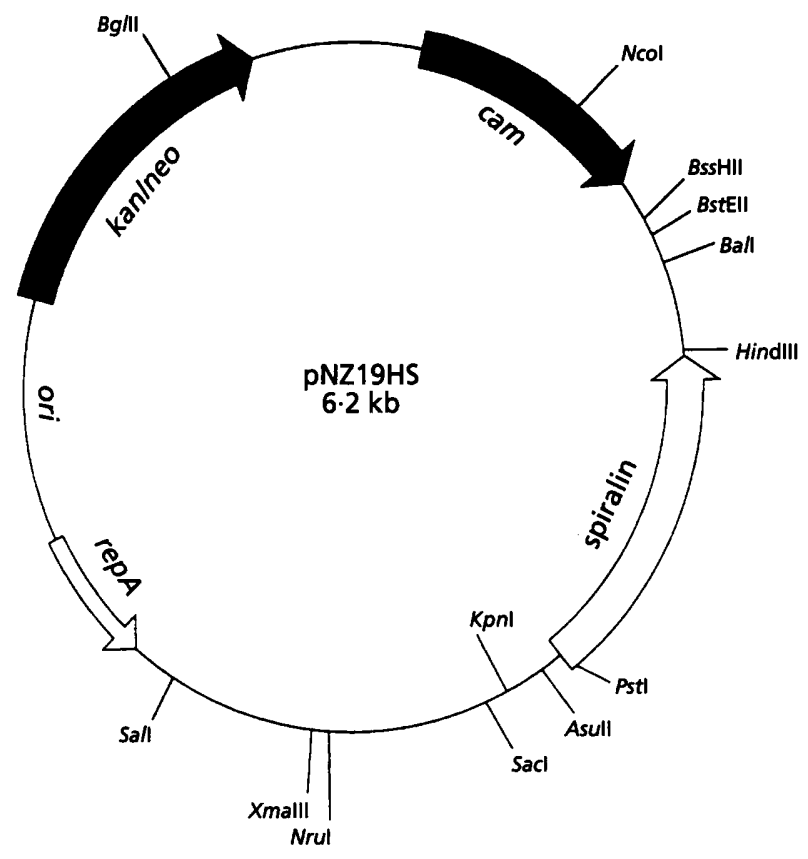

(b)

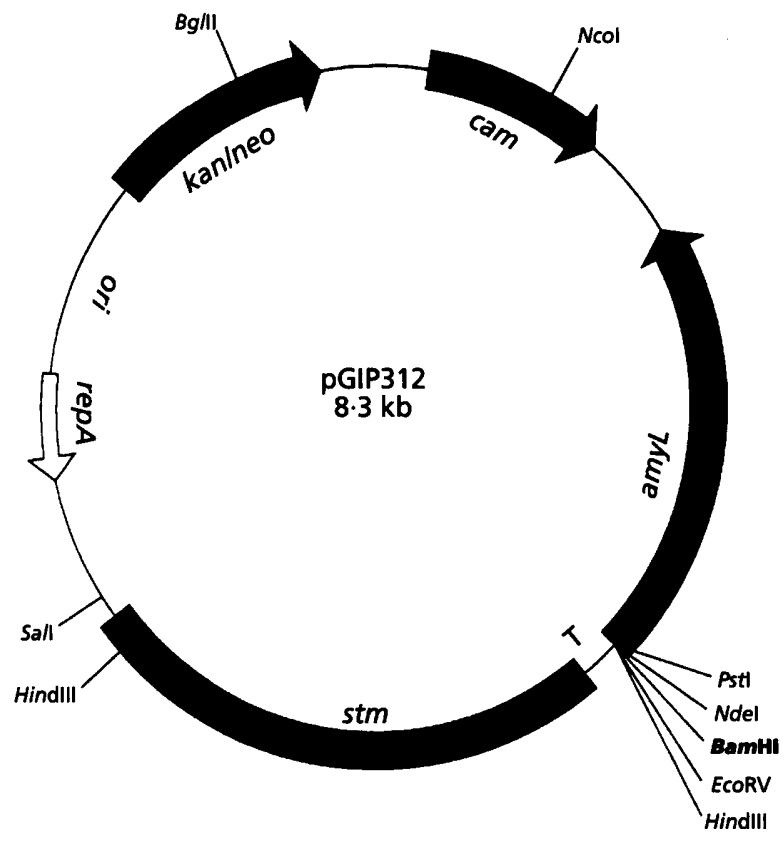

Fig. 1. Restriction maps of plasmids. (a) pNZ19 with the spiralin gene, replicon from $L$. lactis plasmid $\mathrm{pSH71}$, and chloramphenicol (cam) and neomycin (neo)/kanamycin (kan) resistance genes from the Staphylococcus aureus plasmids pUB110 and pC194 (de Vos, 1987; de Vos, personal communication). (b) pGIP312 according to Hols et al., 1992. Streptomycin $(\mathrm{stm})$ resistance gene from the $E$. coli plasmid pMTL23P (Chambers et al., 1988).

acid analyser (Applied Biosystem 120A), at the Department of Medical Biochemistry and Biophysics, Umeå University, Sweden.
Triton X-114 phase separation. Triton X-114 solubilization and temperature phase separation (Bordier, 1981) of membrane fractions from $S$. citri and $A$. laidlawii, and the cytoplasmic fraction (ultracentrifuged) from $A$. laidlawii, were performed essentially as described by Nyström et al. (1992).

Assays of $\alpha$-amylase activity. Bacteria were grown on appropriate agar plates supplemented with $0 \cdot 2 \%$ soluble starch. Amylase producing colonies were detected by staining of the starch with iodine reagent (Smith et al., 1987). To obtain colony replicas, cells were transferred to new plates with nitrocellulose filters (Hybond-C, Amersham) as described by Sundström \& Wieslander (1990). Detection of $\alpha$-amylase activity in SDSpolyacrylamide gels containing $0.25 \%$ soluble starch was done with the iodine reagent as described by Smith et al. $(1987,1988)$ after rinsing the gel four times with $20 \mathrm{mM}$ potassium phosphate buffer $/ 50 \mathrm{mM} \mathrm{NaCl}(\mathrm{pH} \mathrm{7.4)}$ ) supplemented with $0.25 \%$ soluble starch. Amylase activity in liquid solutions was determined spectrophotometrically with Starch Azure (Sigma) as a substrate (Smith et al., 1988).

DNA sequencing. The DNA sequences of one strand of the inserts in the $\alpha$-amylase-producing clones were obtained several times by the dideoxy chain-termination method of Sanger $e t$ al. (1977) using the Sequenase version 2 DNA sequencing kit (USB). Double-stranded plasmid DNA was used as templates together with synthesized oligonucleotide primers.

\section{RESULTS}

\section{Plasmid stability}

The genes for spiralin, a hybrid $\beta$-lactamase, and truncated $\mathrm{E} 2 \mathrm{p}$ were cloned in $\mathrm{pNZ18H}$ or $\mathrm{pNZ19}$. These recombinant plasmids, isolated after transformation into both $E$. coli and $A$. laidlawii were of expected sizes and did not change over time as analysed by restriction enzyme cleavage and gel electrophoresis. pNZ19 with the inserted spiralin gene was structurally and segregationally stable for at least 11 successive inoculations which correspond to about 100 generations.

\section{Expression of foreign genes}

The spiralin, $\beta$-lactamase, truncated E2p and $\alpha$-amylase genes could be expressed in $E$. coli. The first three proteins were detected by polyclonal antibodies, and $\beta$-lactamase and $\alpha$-amylase were also detected by activity measurements. Spiralin (Fig. 2) and $\alpha$-amylase (see below and Fig. 3 ), but not the $\beta$-lactamase nor the truncated E2p, could also be detected in $A$. laidlawii. Expression of the spiralin gene in $A$. laidlawii was observed in cells harbouring the spiralin gene in pNZ19 (called pNZ19HS) but not in cells with the spiralin gene in pNZ18H. The orientation of the spiralin gene in pNZ19HS is shown in Fig. 1a; the spiralin gene cloned in $\mathrm{pNZ18H}$ is oriented in the opposite direction. It was thus only expressed when the gene was oriented in the same direction as the $r e p A$ gene of the vector. The spiralin from pNZ19HS could be detected with both polyclonal (Fig. 2) and monoclonal antibodies directed against purified $S$. citri spiralin, but the level of expression was rather low both in $A$. laidlawii and in E. coli compared to that in S. citri. This observation indicates that the transcription and/or translation signals 


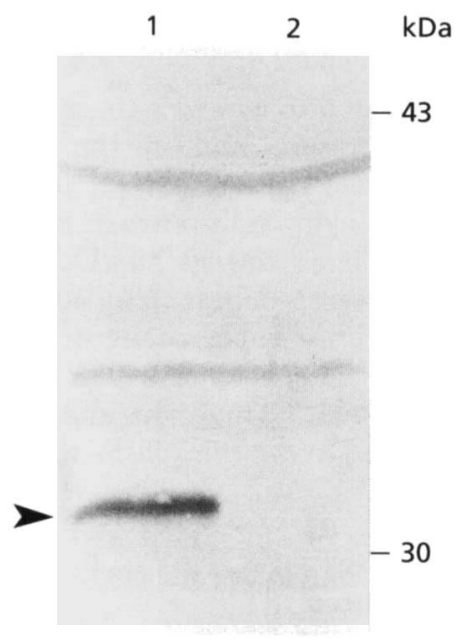

Fig. 2. Expression of spiralin in A. laidlawii. Semi-dry blot filter from an $18 \%$ SDS-polyacrylamide gel which had been run at $120 \mathrm{~V}$ for $24 \mathrm{~h}$. The filter was incubated with polyclonal antibodies against $S$. citri spiralin. Lane 1: cytoplasm from $A$. laidlawii transformed with pNZ19HS. Arrowhead indicates spiralin. Lane 2: cytoplasm from A. laidlawii transformed with pNZ18 vector.

which govern spiralin expression are less efficient in A. laidlawii than in S. citri.

\section{Localization and processing of spiralin}

Spiralin from $S$. citri appeared as a double band in our gel system with apparent molecular masses of about 26.7 and $25.4 \mathrm{kDa}$. Under the same conditions the molecular masses of spiralin produced in $A$. laidlawii and E. coli were estimated to be $31.7 \mathrm{kDa}$ and $32.6 \mathrm{kDa}$, respectively. The $\mathrm{N}$-terminal amino acids of spiralin prepared from transformed $A$. laidlawii were sequenced and the order of the six amino acids obtained (Met Lys Lys Leu Leu Ser) was identical to the $\mathrm{N}$-terminal part of the signal sequence in spiralin from $S$. citri, as deduced from its gene sequence (Chevalier et al., 1990a; Le Hénaff et al., 1991). Hence, the signal peptide seemed to be retained and this could explain the larger size of the protein.

The spiralin in $A$. laidlawii was found predominantly in the cytoplasmic fraction, even if this fraction was purified from contaminating membranes by two extra ultracentrifugation steps. Only a small proportion was detected in the membrane by immunoblotting. This may result from inefficient targeting due to the absence of acyl chain modification. $A$. laidlawii, with or without the spiralin gene, was grown in the presence of highly labelled $\left[{ }^{3} \mathrm{H}\right]$ or $\left[{ }^{14} \mathrm{C}\right]$ palmitic acid $(16: 0)$, but no labelling of spiralin could be detected (data not shown).

The hydrophobic properties of spiralin from $A$. laidlawii containing the signal peptide but lacking lipid modification, was analysed by Triton X-114 phase partitioning. Spiralins from $S$. citri and Spiroplasma melliferum partitioned in the detergent (bottom) phase in the Triton

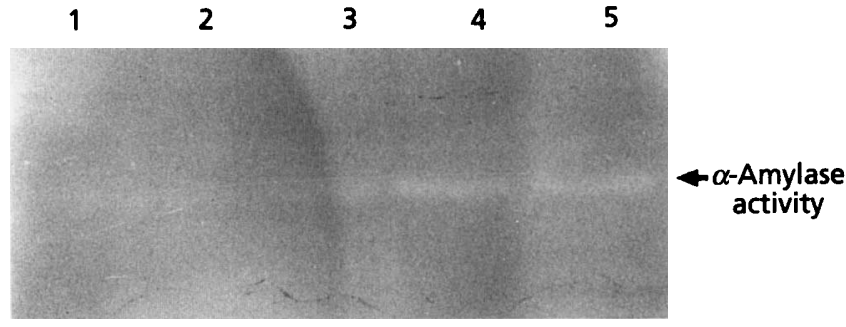

Fig. 3. $\alpha$-Amylase activity in an SDS-polyacrylamide gel. The samples are cell lysates of $A$. laidlawii transformed with the following plasmids: Lanes: 2, pALP-52; 3, pALP-30; 4, pALP-21; 5, pALP-35. Lane 1, untransformed $A$. laidlawii cell lysate as a negative control.

$\mathrm{X}-114$ phase separation as would be expected for lipidmodified membrane proteins. On the other hand spiralin from $A$. laidlawii cytoplasm remained in the aqueous phase. A major $A$. laidlawii membrane acyl protein $\left(\mathrm{T}_{2}\right)$ was used as a control. This protein partitioned in the detergent bottom phase as expected and observed before (Nyström et al., 1992).

\section{Selection of promoter sequences}

The expression of spiralin in $A$. laidlawii was low and two other proteins ( $\beta$-lactamase, truncated $\mathrm{E} 2 \mathrm{p}$ ) were not expressed to detectable levels. Are the expression and translation signals for the genes used much different from the $A$. laidlawii ones? It has been shown that there are considerable differences in the efficiency of certain promoters when used with different lactic bacteria, indicating that endogenous promoters should be used when optimising expression (de Vos \& Simons, 1994). To select $A$. laidlawii endogenous signals, random $A$. laidlawii DNA fragments were cloned in pGIP312. An inserted DNA fragment which contains a promoter, RBS and start codon for translation, and is cloned in the proper amyL ORF of pGIP312, directs the synthesis of $\alpha$-amylase. When this enzyme is synthesized, colonies and the surrounding halo areas become clear if cells are grown on starch-agar plates and later stained with an iodine reagent. The level and localization of $\alpha$-amylase would depend on (i) the strength of the promoter sequence and (ii) the potential signal peptide encoded by the inserted DNA fragment (cf. Hols et al., 1992). When selection was done in E. coli, $0.6 \%$ of the observed colonies presented a starch-debranching activity. Three of these plasmids (pALP-21, pALP-35 and pALP-52) were used to transform $A$. laidlawii. Cells containing any of these three recombinant plasmids expressed the amy $L$ gene, yielding active $\alpha$-amylase (Table 2, Fig. 3). The amount of $\alpha$ amylase was in all cases much lower than in E. coli, but so were the growth rate, cell size and colony size.

In another experiment, $A$. laidlawii cells (clone 2501) were directly transformed by pGIP312, having inserted Sau3A 
Table 2. $\alpha$-Amylase activity in cell lysate of transformed A. laidlawii

\begin{tabular}{|lr|}
\hline Plasmid & \multicolumn{1}{c|}{ Activity* } \\
\hline pGIP312 & $1 \cdot 01 \pm 0 \cdot 32$ \\
pALP-21 & $8 \cdot 36 \pm 0 \cdot 30$ \\
pALP-30 & $11 \cdot 11 \pm 0 \cdot 30$ \\
pALP-35 & $7 \cdot 18 \pm 0 \cdot 35$ \\
pALP-52 & $9 \cdot 76 \pm 0 \cdot 46$ \\
\hline
\end{tabular}

* Activity is expressed as $\alpha$-amylase units per $\mathrm{OD}_{540}$ unit of cells. One unit increases $\mathrm{OD}_{595}$ by one unit $\mathrm{h}^{-1}$ by enzymic hydrolysis of starch azure. Activity was measured in three experiments.

fragments from the genome of $A$. laidlawii. Previously it had been necessary to pass recombinant plasmids through E. coli to amplify the plasmid DNA before transformation of mollicutes, because much plasmid DNA is needed. $A$. laidlawii clone 2501 can be transformed with, for mollicutes, a relatively high frequency. The direct transformation of $A$. laidlawii by recombinant plasmids gave one colony that produced $\alpha$-amylase, pALP- 30 . The insert of pALP-30 gave stronger activity in $A$. laidlawii than the ones selected in E. coli (Table 2). E. coli transformed with pALP-30 also produced $\alpha$-amylase.

Cells were fractionated to estimate the $\alpha$-amylase content in the growth medium, and in the membrane and cytoplasmic fractions. These fractions were analysed for activity of $\alpha$-amylase in SDS-polyacrylamide gels. The apparent molecular mass was $50-55 \mathrm{kDa}$, close to that in $B$. licheniformis. No starch-debranching activity was found in the growth medium supernatant or in the isolated membrane fraction. The $\alpha$-amylase was only detected in the cell lysate (Fig. 3). Thus, the translation product seemed to be retained in the cytoplasm, and the $\alpha$-amylase was not exported.

\section{A. laidlawii sequences}

The production of active $\alpha$-amylase in both $E$. coli and in $A$. laidlawii indicated that expression signals had been cloned that were well recognized by the transcription/ translation machinery in both kind of cells. Seven of the DNA inserts were sequenced and ORFs in the same frame as $\alpha$-amylase and start codons with properly spaced RBS were found. On average, 6.4 bases in the putative RBS (Table 3) could form basepairs with the $3^{\prime}$ end of the $16 \mathrm{~S}$ rRNA of $A$. laidlawii (Woese et al., 1980). In E. coli and B. subtilis the corresponding values are 3-4 and 8.7 bases,

Table 3. Putative promoters selected from A. laidlawii

\begin{tabular}{|c|c|c|c|c|}
\hline Plasmid* & $\begin{array}{c}-35 \\
\text { Regiontł }\end{array}$ & $\begin{array}{l}\text { Distance } \\
\text { in bases }\end{array}$ & $\begin{array}{c}-10 \\
\text { Region } \ddagger\end{array}$ & RBS $₫$ \\
\hline \multirow[t]{2}{*}{ pALP-30 } & TTGAat & 12 & TATAtT & ATCCAGGACAAACT \\
\hline & TTGAat & 17 & TtcAcT & ATCCAGGACAAACT \\
\hline pALP-52 & TTGAtg & 17 & TgTtAc & $\underline{\underline{A} T G} \underline{\underline{A}} G \mathrm{GGA} A \underline{G} \mathrm{G} G \underline{\underline{T}}$ \\
\hline pALP-21 & TTGAgt & 18 & TATACg & ACGGATG \\
\hline pALP-A & TTGgtA & 17 & TAaAAC & $\underline{\text { AGGAAGGTGGT }}$ \\
\hline \multirow[t]{2}{*}{ pALP-B } & TaGAaA & 18 & TAT tAT & $\underline{A}$ GAACTGGTAA \\
\hline & TaGACA & 15 & TAaAgT & AGAACTGGTAA \\
\hline pALP-I & TTGtag & 17 & TATAtT & $\underline{\text { ATGGGTG }}$ \\
\hline \multirow{2}{*}{ PALP-J } & TTtACt & 18 & TATACC & ATTAGGGGAGA \\
\hline & TaatCA & 18 & TATAAT & $\underline{\mathrm{A} T T A G G G G A G A}$ \\
\hline S. citri spiralin\| & TTatt & 20 & TgTAAT & $\underline{\text { AGAAAGGAAAT }}$ \\
\hline A. laidlawii consensus & TTGAnA & Mean 17 & TATAAT & AGAAAGGAGGTGAT \\
\hline A. oculi consensus $\mathrm{g}^{* *}$ & TTCAtn & $17 \cdot 5$ & TATAAM & \\
\hline E. coli consensusg & TTGACA & 17 & TATAAT & TAAGGAGGTGATC \\
\hline Lactococcal consensust† & TTGAnA & $17 \cdot 5$ & TATAAT & \\
\hline
\end{tabular}

* Plasmids pALP-A, -B, -I and -J were selected and tested in E. coli only.

†The -35 sequences were identified visually and by the PC/GENE program sIGNAL in all $A$. laidlawii sequences except in PALP-A and the second $-J$.

$\ddagger$ Bases identical to the $E$. coli -35 or -10 consensus regions are shown in capital letters.

$\int$ Bases that are complementary to the $3^{\prime}$ end of $A$. laidlawii 16S RNA (Woese et al., 1980) are underlined.

$\|$ Chevalier et al. (1990a).

g Bold letters in the consensus indicates that that base was found in that position in at least $70 \%$ of the sequences and normal letters indicate that it was found in at least $40 \%$. W $=\mathrm{A}$ or $\mathrm{T} ; \mathrm{n}=$ any base.

** Knudtson \& Minion (1994).

t† Sequences from de Vos \& Simons (1994). 
respectively. The distance between the RBS and the start codon (calculated as in Maniloff et al., 1994) was between 8 and $14 \mathrm{bp}$, except in pALP-A which had 18 bp but this clone gave a low $\alpha$-amylase activity in $E$. coli. In the mycoplasma virus L2 the distance was $6-15$ bp (Maniloff et al., 1994). Since all the selected promoter regions also functioned in $E$. coli, an obvious way to analyse them was to look for promoter sequences with similarities to the $E$. coli consensus -35 TTGACA and -10 TATAAT sequences. The -35 sequences were identified with the PC/GENE program SIGNAL and visually. The -10 regions were then searched for at a plausible distance from the -35 regions. Putative promoter sequences were found in all inserts (Table 3). For sequences pALP-B and $-\mathrm{J}$ two tandem promoters were identified (Table 3 ). One of the -10 regions given for PALP-30 may not be functional due to there being a very short distance (only 12 bases) to the -35 region. Our other sequences had spacer regions with $15-18$ bases; in $E$. coli the distance is 15-21. A consensus promoter, in which the bases at each position were those most frequently found in the $A$. laidlawii -10 and -35 regions, was derived (Table 3 ).

Most of the translated protein sequences found in-frame with the $\alpha$-amylase did not have the features of typical signal peptides. This was corroborated by the absence of $\alpha$-amylase activity in the growth medium and membrane fraction of transformed $A$. laidlawii cells. The $\alpha$-amylase was, however, active without a signal peptide.

\section{DISCUSSION}

This study shows that pNZ19 and pGIP312 could be used as expression and selection vectors in $A$. laidlawii. We have cloned and expressed a gene encoding the foreign protein spiralin in $A$. laidlawii. We have also selected $A$. laidlawii DNA fragments containing potential promoters, Shine-Dalgarno sequences and start codons. Stability of vectors and cloned genes have previously been a problem in mollicutes. The streptococcal plasmids pVA868 and pVA920 formed deletion derivatives in $A$. laidlawii (Dybvig, 1989), and SpV1, with the G-fragment of the cytadhesion P1 protein from Mycoplasma pneumoniae lost the cloned insert (Marais et al., 1993). The plasmids pNZ18H, pNZ19 and pGIP312 with inserted DNA were all segregationally and structurally stable. Since pNZ19 and PGIP 312 are broad-host-range plasmids and have an origin of replication and a $\operatorname{rep} A$ gene that have high sequence similarities to the corresponding regions of a mycoplasma plasmid pADB201 (de Vos et al., 1989), it is likely that they may function as vectors in other mollicutes as well, provided that there are no interfering UGA codons in the vector.

\section{Spiralin in A. laidlawii}

In $S$. melliferum, spiralin is modified at the $\mathrm{N}$-terminal cysteine with two ester-linked 16 carbon chains and one amide-linked 14-carbon chain, and the signal peptide is cleaved off by an enzyme analogous to the $E$. coli signal peptidase II (Wróblewski et al., 1989; Le Hénaff, 1992; M. Le Hénaff \& $\mathrm{H}$. Wróblewski, unpublished results). The spiralins of S. citri and S. melliferum are $75 \%$ identical in the amino acid sequences, and the sequences around the cleavage sites are identical (Chevalier et al., 1990b). It is therefore anticipated that the spiralin from $S$. citri is modified and cleaved in the same way as the $S$. melliferum spiralin. The larger size of spiralin in $A$. laidlawii is probably due to an uncleaved signal peptide. Retained signal peptides have also been observed for other bacterial lipoproteins when cloned in foreign hosts, e.g. the signal peptide of the mycoplasma lipoprotein VlpC was not cleaved in E. coli (Cleavinger et al., 1994). Our results also indicate that spiralin in $A$. laidlawii is not fatty acylated as in the native host. In $S$. melliferum the spiralin is anchored to the outer surface of the membrane with acyl tails (Wróblewski et al., 1989; Le Hénaff, 1992; M. Le Hénaff \& $\mathrm{H}$. Wróblewski, unpublished results). The spiralin in $A$. laidlawii was mainly found in the cytoplasm. Thus, it seems that the signal peptide is not enough for membrane anchorage and acyl chains are also needed. These observations also indicate that the processing signals of spiralin were not recognized by the $A$. laidlawii cells.

Spiralin constitutes $22 \%(\mathrm{w} / \mathrm{w})$ of the protein in the membrane of $S$. citri (Wróblewski et al., 1977). However in $A$. laidlawii and in $E$. coli the amounts were much lower. Over-expression of membrane proteins in E. coli has proven to be more difficult than overproduction of soluble proteins (Schertler, 1992). Since spiralin is not processed as in spiroplasmas (see above), this could limit membrane insertion which in turn could prevent expression. The expression of other cloned proteins in mollicutes has also been low. The G-fragment of the cytadhesin P1 protein could be detected with antibodies but not visualized in a Coomassie-stained gel when expressed in S. citri (Marais et al., 1993). Activity of the kanamycin/neomycin nucleotidyl transferase (encoded by the resistance gene in the vector) could be detected in $A$. laidlawii but the amounts of this protein were also too low to be visualized by Coomassie staining. The low expression in $A$. laidlawii could be due to possible differences in promoter and upstream element usage. Very few promoters have so far been sequenced from $A$. laidlawii genes.

\section{A. laidlawii promoter sequences}

The selection of functional $A$. laidlawii promoter, RBS and start codon was achieved with a truncated $\alpha$-amylase gene. This has been used previously as a reporter gene to find expression and secretion signals from Enterococcus faecalis (Hols et al., 1992), B. subtilis (Smith et al., 1987; 1988) and L. lactis DNA (Perez-Martinez et al., 1992). Selection in either $E$. coli or $A$. laidlawii gave expression of $\alpha$-amylase in re-transformed $A$. laidlawii and $E$. coli for all sequences that were tested. Sequences similar to $E$. coli promoter regions were found (Table 3 ). On average, $8 \cdot 2$ of the 12 bases in the proposed promoter regions were identical to the $E$. coli consensus, a value similar to that found for $E$. coli promoters. There was a higher similarity to the E. coli -10 than to the -35 region; this has been observed in other mollicute promoter regions (Muto et al., 1992), and could be due to the high mol \% of adenine 
and thymine in the genome of these bacteria. The $A$. laidlawii putative promoter sequences are also very similar to the promoters selected from $A$. oculi (Knudtson \& Minion, 1994) and Lactococcus sequences (de Vos et al., 1994; Table 3). However, in contrast to our study only $10 \%$ of the $A$. oculi sequences selected in E. coli were functional in $A$. oculi (Knudtson \& Minion, 1994). It is noteworthy that the sequence selected directly in $A$. laidlawii gave the highest $\alpha$-amylase activity in this organism (Table 2). The promoter of spiralin (Table 3 ) has a longer spacer, and the -35 region a lower similarity, to the $E$. coli promoter than the selected putative $A$. laidlawii promoters. This could be one reason for the low expression of spiralin in $A$. laidlawii and $E$. coli, another reason could be reduced stability of the mRNA. Since the sequences that are functional in $A$. laidlawii are so similar to the $E$. coli consensus promoters, this can not explain the difficulties in expressing $E$. coli genes in mollicutes. It has been suggested that regions upstream of the promoter contribute to the efficiency of transcription initiation in $L$. lactis (de Vos \& Simons, 1994). We do not know if any other part beside the proposed -35 and -10 regions of the inserts influenced expression in $A$. laidlawii. However, we now have sequences that can promote the expression of foreign genes in $A$. laidlawii and they have been useful for the expression of an active lipid-synthesizing enzyme from $E$. coli in $A$. laidlawii (T. K. Jarhede et al., unpublished results).

\section{ACKNOWLEDGEMENTS}

We thank Dr W. M. de Vos (Ede, The Netherlands) for providing us with pNZ18 and pNZ19; Dr P. Hols (Louvain-LaNeuve, Belgium) for pGIP312; Dr H. Wróblewski (Rennes, France) for pES1, S. citri strain R8A2 and polyclonal and monoclonal antibodies against spiralin; P.-I. Ohlsson (Umea, Sweden) for performing the amino acid sequence analysis; Bengt-Harald Jonsson for discussions about the PCR experiment and V. Tegman for excellent technical assistance. This work was supported by the Swedish Natural Science Research Council. M.L.H. was the recipient of postdoctoral studentships from the Wenner-Gren and Dufrenoy Foundations and from 'Région Bretagne' (program BRITTA).

\section{REFERENCES}

Bordier, C. (1981). Phase separation of integral membrane proteins in Triton X-114 solution. J Biol Chem 256, 1604-1607.

Bové, J. M., Foissac, X. \& Saillard, C. (1993). Spiralins. In Subcellular Biocbemistry, vol. 20: Mycoplasma Cell Membranes, pp. 203-223. Edited by S. Rottem \& I. Kahanen. New York: Plenum Press.

Broome-Smith, J. K., Tadayyon, M. \& Zhang, Y. (1990). $\beta$-lactamase as a probe of membrane protein assembly and protein export. Mol Microbiol 4, 1637-1644.

Casadaban, M. J. \& Cohen, S. N. (1980). Analysis of gene control signals by DNA fusion and cloning in Escherichia coli. J Mol Biol 138, 179-207.

Chambers, S. P., Prior S. E., Barstow, D. A. \& Minton, N. P. (1988). The pMTL nic-cloning vectors, I. Improved pUC polylinker regions to facilitate the use of sonicated DNA for nucleotide sequencing. Gene 68, 139-149.

Chevalier, C., Saillard, C. \& Bové, J. M. (1990a). Organization and nucleotide sequences of the Spiroplasma citri genes for ribosomal protein S2, elongation factor Ts, spiralin, phosphofructokinase, pyruvate kinase, and an unidentified protein. $J$ Bacteriol 172, 2693-2703.

Chevalier, C., Saillard C. \& Bové, J. M. (1990b). Spiralins of Spiroplasma citri and Spiroplasma melliferum: amino acid sequences and putative organization in the cell membrane. J Bacteriol 172, 6090-6097.

Cleavinger, C. M., Kim, M. F. \& Wise, K. S. (1994). Processing and surface presentation of the Mycoplasma byorbinis variant lipoprotein VlpC. $J$ Bacteriol 176, 2463-2467.

Dybvig, K. (1989). Transformation of Acholeplasma laidlawii with streptococcal plasmids pVA868 and pVA920. Plasmid 21, 155-160.

Dybvig, K. (1992). Gene transfer. In Mycoplasmas: Molecular Biology and Pathogenesis, pp. 355-361. Edited by J. Maniloff, R. N. McElhaney, L. R. Finch \& J. B. Baseman. Washington, DC: American Society for Microbiology.

Hanahan, D. (1985). Techniques for transformation of E. coli. In DNA Cloning: a Practical Approach, vol. 1, pp.109-135. Edited by D. M. Glover. Oxford: IRL Press.

Hayashi, S. \& Wu, H. C. (1990). Lipoproteins in bacteria. J Bioenerg Biomembr 22, 451-471.

Hols, P., Baulard, A., Garmyn, D., Dalplace, B., Hogan, S. \& Delcour, J. (1992). Isolation and characterization of genetic expression and secretion signals from Enterococcus faecalis through the use of broad-host-range $\alpha$-amylase probe vectors. Gene 118, 21-30.

Knudtson, K. L. \& Minion, F. C. (1994). Use of lac gene fusions in the analysis of Acboleplasma upstream gene regulatory sequences. $J$ Bacteriol 176, 2763-2766.

Laemmli, U. K. (1970). Cleavage of structural proteins during the assembly of the head of bacteriophage T4. Nature 227, 680-685.

Le Hénaff, M., Brenner, C., Fontenelle, C., Delamarche, C. \& Wróblewski, H. (1991). Does spiralin possess a cleavable $\mathrm{N}$ terminal signal sequence? C R Acad Sci Paris Ser III 312, 189-195.

Le Hénaff, M. (1992). Biogénèse et topographie de la spiraline chez les spiroplasmes et expression de son gène chez Escherichia coli. $\mathrm{PhD}$ thesis. Université de Rennes I, France.

Maniloff, J., McElhaney, R. N., Finch, L. R. \& Baseman, J. B. (1992). Mycoplasmas: Molecular Biology and Pathogenesis. Washington, DC: American Society for Microbiology.

Maniloff, J., Kampo, G. J. \& Dascher, C. C. (1994). Sequence analysis of a unique temperate phage: mycoplasma virus L2. Gene 141, 1-8.

Marais, A., Bové, J. M., Dallo, S. F., Baseman, J. B. \& Renaudin, J. (1993). Expression in Spiroplasma citri of an epitope carried on the $\mathrm{G}$ fragment of the cytadhesin P1 gene from Mycoplasma pneumoniae. $J$ Bacteriol 175, 2783-2787.

Matsudaira, P. (1987). Sequence from picomole quantities of proteins electroblotted onto polyvinylidene difluoride membranes. $J$ Biol Chem 262, 10035-10038.

Mouchès, C., Candresse, T., Barroso, G., Saillard, C., Wróblewski, H. \& Bové, J. M. (1985). Gene for spiralin, the major membrane protein of the helical mollicute Spiroplasma citri: cloning and expression in Escherichia coli. J Bacteriol 164, 1094-1099.

Muto, A., Andachi, Y., Yamao, F., Tanaka, R. \& Osawa, S. (1992). Transcription and translation. In Mycoplasmas: Molecular Biology and Pathogenesis, pp. 331-347. Edited by J. Maniloff, R. N. McElhaney, L. R. Finch \& J. B. Baseman. Washington, DC: American Society for Microbiology. 
Nystrőm, S., Johansson, K.-E. \& Wieslander, Å. (1986). Selective acylation of membrane proteins in Acboleplasma laidlawii. Eur $J$ Biochem 156, 85-94.

Nyström, S., Wallbrandt, P. \& Wieslander, Å. (1992). Membrane protein acylation. Preference for exogenous myristic acid or endogenous saturated chains in Acholeplasma laidlawii. Eur J Biochem 204, 231-240.

Perez-Martinez, G., Kok, J., Venema, G., van Dijl, J. M., Smith, H. \& Bron, S. (1992). Protein export elements from Lactococcus lactis. Mol \& Gen Genet 234, 401-411.

Piggot, R. P., Rossiter, A., Ortlepp, S. A., Pembroke, J. T. \& Ollington, J. F. (1984). Cloning in Bacillus subtilis of an extremely thermostable alpha amylase: comparison with other cloned heatstable alpha amylases. Biochem Biophys Res Commun 122, 175-183.

Prentki, P. \& Krisch, H. M. (1984). In vitro insertional mutagenesis with a selectable DNA fragment. Gene 29, 303-313.

Rietveld, A. G., Killian, J. A., Dowhan, W. \& De Kruiff, B. (1993). Polymorphic regulation of membrane phospholipid composition in Escherichia coli. J Biol Chem 268, 12427-12433.

Rilfors, L., Wieslander, Å. \& Lindblom, G. (1993). Regulation and physicochemical properties of the polar lipids in Acholeplasma laidlawii. In Subcellular Biochemistry, vol. 20: Mycoplasma Cell Membranes, pp. 109-166. Edited by S. Rottem \& I. Kahane. New York: Plenum Press.

Saglio, P., Lhospital, M., Laflèche, D., Dupont, G., Bové, J. M., Tully, J. G. \& Freundt, E. A. (1973). Spiroplasma citri gen. and sp. n.: a mycoplasma like organism associated with 'stubborn' disease of citrus. Int J Syst Bacteriol 23, 191-204.

Sambrook, J., Fritsch, E. F. \& Maniatis, T. (1989). Molecular Cloning: a Laboratory Manual. Cold Spring Harbor, NY: Cold Spring Harbor Laboratory.

Sanger, F., Nicklen, S. \& Coulson, A. R. (1977). DNA sequencing with chain-terminating inhibitors. Proc Natl Acad Sci USA 74, 5463-5467.

Schertler, G. F. X. (1992). Overproduction of membrane proteins. Curr Opin Struct Biol 2, 534-544.

Simonen, M. \& Palva, I. (1993). Protein secretion in Bacillus species. Microbiol Rev 57, 109-137.

Singer, S. J. \& Nicolson, G. L. (1972). The fluid mosaic model of the structure of cell membranes. Science 175, 720-731.

Sladek, T. L. \& Maniloff, J. (1983). Polyethylene glycol-dependent transfection of Acholeplasma laidlawii with mycoplasma virus L2 DNA. J Bacteriol 155, 734-741.

Sladek, T. L., Nowak, J. A. \& Maniloff, J. (1986). Mycoplasma restriction: Identification of a new type of restriction specificity for DNA containing 5-methylcytosine. J Bacteriol 165, 219-225.

Smith, H., Bron, S., van EE, J. \& Venema, G. (1987). Construction and use of signal sequence selection vectors in Escherichia coli and Bacillus subtilis. J Bacteriol 169, 3321-3328.
Smith, H., de Jong, A., Bron, S. \& Venema, G. (1988). Characterization of signal-sequence-coding regions selected from the Bacillus subtilis chromosome. Gene 70, 351-361.

Sundström, T. K. \& Wieslander, Å. (1990). Plasmid transformation and replica filter plating of Acboleplasma laidlawii. FEMS Microbiol Lett 72, 147-152.

Tanaka, R., Muto, A. \& Osawa, S. (1989). Nucleotide sequence of tryptophan tRNA gene in Acboleplasma laidlawii. Nucleic Acids Res 17, 5842.

Tegman, V., Wallbrandt, P., Nyström, S., Johansson, K.-E., Jonsson, B.-H. \& Wieslander, Å. (1987). Cloning and expression of Acboleplasma laidlawii membrane acyl proteins in Escherichia coli. Isr J Med Sci 23, 408-413.

de Vos, W. M. (1987). Gene cloning and expression in lactic streptococci. FEMS Microbiol Rev 46, 281-295.

de Vos, W. M. \& Simons, G. F. M. (1994). Gene cloning and expression systems in Lactococci. In Genetics and Biotechnology of Lactic Acid Bacteria, pp. 52-105. Edited by M. J. Gasson \& W. M. de Vos. Glasgow: Blackie Academic \& Professional.

de Vos, W. M. Kuiper, H., Levar, A. \& Ventris, J. (1989). Heterogrammic replication of Lactococcus lactis plasmid $\mathrm{pSH} 71$ is regulated by a repressor-operator control circuit. ASM Annual Meeting, New Orleans, abstract H276.

Wallbrandt, P., Tegman, V., Jonsson, B.-H. \& Wieslander, Å. (1992). Identification and analysis of the genes coding for the putative pyruvate dehydrogenase enzyme complex in Acholeplasma laidlawii. J Bacteriol 174, 1388-1396.

Whitcomb, R. F. (1983). Culture media for spiroplasmas, In Methods in Mycoplasmology, vol.1, pp. 147-158. Edited by S. Razin \& J. G Tully. New York: Academic Press.

Wieslander, Å., Boyer, M. J. \& Wróblewski, H. (1992). Membrane protein structure. In Mycoplasmas: Molecular Biology and Pathogenesis, pp. 93-112. Edited by J. Maniloff, R. N. McElhaney, L. R. Finch \& J. B. Baseman. Washington, DC: American Society for Microbiology.

Wieslander, Å., Rilfors, L., Dahlqvist, A., Jonsson, J., Hellberg, S., Rănnar, S., Sjostróm, M. \& Lindblom, G. (1994). Similar regulatory mechanisms despite differences in membrane lipid composition in Acholeplasma laidlawii strains A-EF22 and B-PG9. A multivariate data analysis. Biocbim Biophys Acta 1191, 331-342.

Woese, C. R., Maniloff, J. \& Zablen, L. B. (1980). Phylogenetic analysis of the mycoplasmas. Proc Natl Acad Sci US A 77, 494-498.

Wróblewski, H., Johansson, K.-J. \& Hjertén, S. (1977). Purification and characterization of spiralin, the main protein of the Spiroplasma citri membrane. Biochim Biophys Acta 465, 275-289.

Wróblewski, H., Nyström, S., Blanchard, A. \& Wieslander, Å. (1989). Topology and acylation of spiralin. J Bacteriol 171, 5039-5047.

Received 30 December 1994; revised 19 April 1995; accepted 4 May 1995. 